AUTHOR CORRECTION

\title{
Author Correction: A randomised controlled feasibility trial of E-health application supported care vs usual care after exacerbation of COPD: the RESCUE trial
}

Mal North (iD, Simon Bourne (D), Ben Green, Anoop J. Chauhan (iD), Tom Brown, Jonathan Winter (iD), Tom Jones (iD, Dan Neville, Alison Blythin (D), Alastair Watson (iD), Matthew Johnson (iD), David Culliford (D), Jack Elkes (iD, Victoria Cornelius and Tom M. A. Wilkinson (D)

npj Digital Medicine (2020)3:150; https://doi.org/10.1038/s41746-020-00360-w

Correction to: npj Digital Medicine https://doi.org/10.1038/s41746020-00347-7, published online 30 October 2020

The original version of the published Article had an error in the Abstract. The tenth sentence of the Abstract has been corrected to the following: Exacerbations tended to be less frequent in the digital arm compared to usual care; 18 vs 34 events. The HTML and PDF versions of the Article have been corrected.

\begin{abstract}
cc (i) Open Access This article is licensed under a Creative Commons Attribution 4.0 International License, which permits use, sharing, adaptation, distribution and reproduction in any medium or format, as long as you give appropriate credit to the original author(s) and the source, provide a link to the Creative Commons license, and indicate if changes were made. The images or other third party material in this article are included in the article's Creative Commons license, unless indicated otherwise in a credit line to the material. If material is not included in the article's Creative Commons license and your intended use is not permitted by statutory regulation or exceeds the permitted use, you will need to obtain permission directly from the copyright holder. To view a copy of this license, visit http://creativecommons. org/licenses/by/4.0/.
\end{abstract}

(c) The Author(s) 2020 